\title{
Correction to: The role of C-afferents
} in mediating neurogenic vasodilatation in plantar skin after acute sciatic nerve injury in rats

Tao Zhang ${ }^{1}$, Jiahui $\mathrm{Niu}^{2}$, Yaxian Wang ${ }^{2}$, Junying Yan $^{3}$, Wen $\mathrm{Hu}^{2,5}$ and Daguo Mi ${ }^{4^{*}}$ (D)

\section{Correction to: BMC Neurosci (2020) 21:15} https://doi.org/10.1186/s12868-020-00564-6

Following publication of the original article [1], the authors identified an error in the author name of Jiahui Niu.

The incorrect author name is: Jianhui Niu.

The correct author name is: Jiahui Niu.

The author group has been updated above and the original article [1] has been corrected.

\section{Author details}

${ }^{1}$ Department of Radiology, The Third People's Hospital of Nantong City and The Third Nantong Hospital Afliated to Nantong University, Nantong 226001, Jiangsu, China. ${ }^{2}$ Key Laboratory for Neuroregeneration of Ministry of Education and Co-innovation Center for Neuroregeneration of Jiangsu Province, Nantong University, Nantong 226001, Jiangsu, China. ${ }^{3}$ School of Medicine, Nantong University, Nantong 226001, Jiangsu, China. ${ }^{4}$ Department of Orthopedics, Nantong City Hospital of Traditional Chinese Medicine, Nantong 226001, Jiangsu, China. ${ }^{5}$ Present Address: Department of Neurochemistry, Inge Grundke-lqbal Research Floor, New York State Institute for Basic Research in Developmental Disabilities, Staten Island, NY 10314, USA.

\section{Reference \\ 1. Zhang T, Niu J, Wang Y, Yan J, Hu W, Mi D. The role of C-afferents in medi- ating neurogenic vasodilatation in plantar skin after acute sciatic nerve injury in rats. BMC Neurosci. 2020;21:15. https://doi.org/10.1186/s1286 8-020-00564-6.}

\section{Publisher's Note}

Springer Nature remains neutral with regard to jurisdictional claims in published maps and institutional affiliations.

Published online: 27 April 2020

The original article can be found online at https://doi.org/10.1186/s1286 8-020-00564-6.

*Correspondence: 2535213700@qq.com

${ }^{4}$ Department of Orthopedics, Nantong City Hospital of Traditional

Chinese Medicine, Nantong 226001, Jiangsu, China

Full list of author information is available at the end of the article

(c) The Author(s) 2020. This article is licensed under a Creative Commons Attribution 4.0 International License, which permits use, sharing, adaptation, distribution and reproduction in any medium or format, as long as you give appropriate credit to the original author(s) and the source, provide a link to the Creative Commons licence, and indicate if changes were made. The images or other third party material in this article are included in the article's Creative Commons licence, unless indicated otherwise in a credit line to the material. If material is not included in the article's Creative Commons licence and your intended use is not permitted by statutory regulation or exceeds the permitted use, you will need to obtain permission directly from the copyright holder. To view a copy of this licence, visit http://creativecommons.org/licenses/by/4.0/. The Creative Commons Public Domain Dedication waiver (http://creativecommons.org/publicdomain/zero/1.0/) applies to the data made available in this article, unless otherwise stated in a credit line to the data. 